\title{
Revegetation of artificial grassland improve soil organic and inorganic carbon and water of abandoned mine
}

\author{
Z. Yang ${ }^{1,2}$, H.M. Hao ${ }^{1,2}$, D. Wang ${ }^{1,2}$, X.F. Chang ${ }^{1,2}$, Y.J. Zhu ${ }^{1,2}$, G.L, Wu ${ }^{1,2 *}$

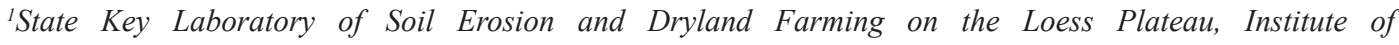 \\ Soil and Water Conservation, Northwest A \& F University, Yangling, Shaanxi 712100, China. \\ ${ }^{2}$ Institute of Soil and Water Conservation, Chinese Academy of Sciences and Ministry of Water \\ Resources, Yangling, Shaanxi 712100, China. *Corresponding author: gaolinwu@gmail.com
}

\begin{abstract}
Mining and related activities caused plant productivity and soil carbon content reduced in arid and semi-arid ecosystems. Soil carbon plays an essential role in ecosystem stability. Soil carbon and associated changes in soil property were important drivers and indicators of ecosystem recovery at post-mining areas. We selected 5, 10 and 20 years of restoration lands to examine the effect of artificial grassland on vegetation community and soil property. Results showed that artificial grassland markedly increased the biomass, canopy coverage and soil carbon content, but decreased soil bulk density and soil water content. After 10-year of restoration, both the biomass and soil organic carbon (SOC) content reached the peak, however, soil bulk density and soil water content arrived the lowest at depth of $0-20 \mathrm{~cm}$ and got the highest at depth of 20-30 cm. At 20-year of restoration land, the biomass (above- and belowground) and SOC content $(0-30 \mathrm{~cm})$ significantly decreased by $46.2 \%$ and $67.0 \%$ with compared to 10 -year of restoration land, while soil bulk density of $0-10 \mathrm{~cm}$ and $10-20$ cm depths increased by $7.8 \%$ and $21.4 \%$, respectively, soil water content $(0-30 \mathrm{~cm})$ increased by $11.6 \%$. It was evident that artificial grassland as an effective ecological restoration approach could improve soil physicchemical property, while properly anthropogenic perturbations were also needed to stimulate plant growth.
\end{abstract}

Keywords: Artificial grassland, mine soil restoration, soil physic-chemical property, vegetation community 


\section{Introduction}

Mining and related activities have drastically altered earth's ecosystems, which caused drastic perturbation on terrestrial ecosystems and led to severe soil degradation (Akala and Lal, 2000). Many studies had documented that soil disturbance through mining operations have changed soil properties, such as lower soil organic matter content, destroyed soil structure, increased bulk density, lower soil fertility and reduced microbial activity (Ussiri et al., 2006; Shukla et al., 2011). The original vegetation was inevitably destroyed and soil was lost or buried by waste in the process of removing coal. All of those limited the growth of vegetation and resulted in the decrease of plant litter. With plant litter input reduced, a severe loss of SOC occurred. SOC is a very important soil component and it is essential for protecting and maintaining soil structure and quality (Li et al., 2013). SOC decreased could accelerated soil erosion and topsoil removal (Ussiri et al., 2006). A general Mining Act had been passed as early as 1854 to specify the rules for mining in relation to the land. Reclamation of mine spoils sought to return the disturbed soil ecosystem to a productive state (Barnhisel and Hower, 1997). This involves the restoration of mine soils' fertility, improvement of soil quality, reestablishment of vegetation and enhancement of biomass productivity. The methods that brought to restoration of mine spoils must be done in a way that could surly maximize the long-term sustainability of the ecosystem (Shrestha and Lal, 2011). Some studies had found that vegetation plays a major role in improving the physical, chemical and biological properties of mine soil (Bradshaw, 1987). Enhanced biomass production could increase SOC concentration in reclaimed mine spoils (Akala and Lal, 2000, 2001). Ussiri et al. (2006) found that tree plantation establishment had great potential for SOC sequestration in re- claimed mine soil. Artificial grassland establishment also significantly improved SOC in the topsoil $(\mathrm{Wu}$ et al., 2010). So reclamation of drastically disturbed mine soil and subsequent planting trees or grass could rapidly build-up carbon in the soil (Nyamadzawo et al., 2008; Lv and Liang, 2012).

Several studies about the impacts of reclamation and artificial grassland on evolution of soil properties over time had been reported (Nyamadzawo et al., 2008; Keskin and Makineci, 2009; Juwarkar et al., 2010; Wu et al., 2010). Nyamadzawo et al. (2008) studied reclaimed minesoils characterized by distinct reclamation age chronosequences and found some relationships emerged between amount of time since reclamation and soil carbon stocks. Akala and Lal (2001) studied a chronosequence of reclaimed lands found that reclamation of mined lands decreased bulk density over a period of 20 to 30 years. Establishment of pasture increased SOC pool by 50 to $75 \mathrm{mg}$ ha $^{-1} \mathrm{yr}^{-1}$ over 20 to 30 years under reclamation. Wu et al. (2010) found that 6-year artificial grassland significantly increased soil carbon storage than 3-year artificial grassland. Zhao et al. (2013) reported that soil organic matter and available nitrogen showed a significantly increased in $0-40 \mathrm{~cm}$ depth with increasing of reclamation time.

In mining areas, land surface was mined for coal and subsequently reclaimed. Due to the development of mining, the main components under the soil layer were sandstone and siltstone which derived from the mine (Fu et al., 2010). Soil structure was severely destroyed and soil erosion was serious. In order to restore local ecosystems, we considered to reclamation of mine soil by establishing artificial grassland. Therefore, the primary objectives of our study were to evaluate changes in selected physical and chemical properties of restoration land, in order to strengthen 
the database on plant community characteristics and soil properties in response to distinct years of planting grass and provide an appropriate botanical reclamation method for the surface of coal mines in the study area.

\section{Materials and Methods}

\subsection{Study sites}

This experiment was conducted in Heidaigou mining areas, Inner Mongolian Autonomous Region, China, which is located in the northern Loess Plateau. The mean annual temperature is $7.2{ }^{\circ} \mathrm{C}$, ranging from $-30.9^{\circ} \mathrm{C}$ to $38.3^{\circ} \mathrm{C}$. The mean annual precipitation is $404.1 \mathrm{~mm}$, with a main rain period in July, August and September, which accounts for about $60 \% \sim 70 \%$ of annual rainfall. Annual evaporation capacity is 2082.2 $\mathrm{mm}$. The annual cloud-free solar radiation was about $3119.3 \mathrm{~h}$ (Zhang, 2012). The climate is cold and dry in the winter and spring, rainy and hot in the summer. In this study, we selected three lands with different number of years in restoration, 5-year $\left(39^{\circ} 46.955^{\prime} \mathrm{N}\right.$, $110^{\circ} 16.310^{\prime} \mathrm{E}, 1280 \mathrm{~m}$, reclaimed in 2009), 10-year $\left(39^{\circ} 46.941^{\prime} \mathrm{N}, 110^{\circ} 17.9181^{\prime} \mathrm{E}, 1286 \mathrm{~m}\right.$, reclaimed in 2005), and 20-year ( $39^{\circ} 47.138^{\prime} \mathrm{N}, 110^{\circ} 16.482^{\prime} \mathrm{E}$, $1267 \mathrm{~m}$, reclaimed in 1994), which all dominated by Stipa capillata Lin and Agropyron cristatum. Predominant soil of the region is loessinal soil. The regions are owned and operated by Shenhua Coal Company. The restoration years of all sites were detailed record. The method and mode of mining and reclamation were identical and standardized for all the sites. In the process of mining and reclamation, vegetation was cleared and the topsoil was removed. The overburden on top of the coal seam was then excavated and placed in areas that have already been mined. All sites were close, differences in soil conditions, vegetation types and other hydrocli-matological factors were minimized. This allows for a direct comparison.

\subsection{Experimental design}

In this study, we compared three restoration lands with different number of years in restoration: 5-year, 10-year and 20-year artificial establishment of Stipa capillata Lin and Agropyron cristatum. The revegetation and management of all sites complied with the standards what the company issued. Revegetation of grass with the same plant density, irrigating water to ensure grass survival at the beginning of restoring. Then grass growth mainly depended on rainfall. We selected 3 lands for every reclamation year and 3 sample plots were established in every reclaimed land. When biomass had reached its peak, we randomly selected three parallel $1 \mathrm{~m} \times 1 \mathrm{~m}$ quadrats in each of plots. Investigating for above- and belowground biomass, canopy coverage, height and collecting soil samples.

At the end of the growing season, aboveground biomass was harvested at soil level and put into envelope. Each was weighed fresh and then was weighed after drying at $80^{\circ} \mathrm{C}$ for $48 \mathrm{~h}$. To measure the belowground biomass, a $9 \mathrm{~cm}$ diameter root augur was used to take three soil samples for each depth in 0-10, 10-20, 20$30 \mathrm{~cm}$. Samples taken at the same layer then mixed to create a single sample. A $2 \mathrm{~mm}$ sieve was used to isolate the majority of plant roots from each sample. No attempt was made to distinguish from living and dead roots. The isolated roots were oven-dried at 75 ${ }^{\circ} \mathrm{C}$ then weighed.

\subsection{Soil sampling and determination}

Soil bulk density of each layer (0-10, 10-20, 20-30 $\mathrm{cm}$ ) was measured by using a soil bulk sampler with a $5 \mathrm{~cm}$ diameter and a $5 \mathrm{~cm}$ high stainless steel cutting ring (3 replicates) at points adjacent to where soil samples had been collected for chemical analysis. The original volume of each soil core and their dry mass 
were measured after oven-drying at $105{ }^{\circ} \mathrm{C}$. Soil water content was measured gravimetrically and expressed as a ratio of soil water to dry soil weight. Three soil samples were collected at different soil depths (from 0-10, 10-20 and 20-30 cm, respectively) by using a bucket auger from each quadrat. Soil samples at the same depth in each sampling quadrat were mixed. Then, all soil samples were air-dried and then passed through a $0.14 \mathrm{~mm}$ sieve. The SOC content were determined by wet oxidation with potassium dichromate $\left(\mathrm{K}_{2} \mathrm{Cr}_{2} \mathrm{O}_{7}\right)$ and dry combustion with a carbon analyzer through Mebius method by the Walkley-Black acid digestion. Soil inorganic carbon (SIC) was analyzed with the calcimeter. The calcimeter method was based on the reaction of SIC with $\mathrm{HCl}$ to $\mathrm{CO}_{2}$. The volume of evolved gas was measured by the displacement of water column. The method was extensively described in Horváth et al. (2005). Between 1 and $10 \mathrm{~g}$ was scaled, depending on the reaction of the sample with $10 \% \mathrm{HCl}$ in a preliminary test (Truong et al., 2013).

\subsection{Data analysis}

All data were expressed as mean \pm standard error of mean. Statistical analyses were conducted by using SPSS software (ver.21.0). The differences in soil properties and values of vegetation community among sites were compared by using one-way analysis of variance (ANOVA) procedures. Significant differences were evaluated at 0.05 level.

\section{Result}

\subsection{Response of plant community}

In this study, restoration land markedly increased total plant coverage, height, above- and belowground biomass over time (Table 1; Figure 1). When res- toration of 10 years, the biomass reached the peak both above- $\left(148.36 \pm 14.25 \mathrm{~g} \mathrm{~m}^{-2}\right)$ and belowground $\left(504.19 \pm 119.98 \mathrm{~g} \mathrm{~m}^{-2}\right)$, however they decreased by $53 \%$ and $44 \%$ until 20 years restoration, respectively (Table 1).

For aboveground biomass, there was a significant difference between restoration of 10-year and restoration of 5-year and 20-year $(p<0.05)$, as well as the total coverage (Figure 1).

\subsection{Response of soil properties}

There was a significant effect of soil depth on soil properties among all restoration lands in this study (Figure 2). 10-year of restoration land had a lower soil water content and soil bulk density (at depth of 0-10 $\mathrm{cm}$ and $10-20 \mathrm{~cm}$ ) than 5-year and 20-year of restoration lands. (Figure 2B, D).

At depth of 20-30 cm, there was a significant difference for soil water content between 10-year of restoration land and both 5-year and 20-year of restoration lands $(p<0.05)$. For the soil bulk density of 20-30 cm depth, 5-year of restoration land was different from 10-year and 20-year of restoration lands $(p<0.05)$.

For SOC content, 10-year of restoration land showed a markedly increased throughout different soil depths. But the similar trend was not found for SIC content. For SIC content, 5-year and 20-year of restoration lands were all lower than 10-year of restoration land at depth of $0-10 \mathrm{~cm}$, but opposite result was showed at depth of 20-30 cm. At depth of $0-10 \mathrm{~cm}$, both soil organic carbon $(p<0.05)$ and inorganic carbon content $(p<0.05)$ showed a difference between 10-year of restoration land and both 5-year and 20-year of restoration lands, while at depth of 10-20 cm, only SOC content ( $p<0.05)$ showed the difference (Figure 2A, C). 
Table 1. Dominant species and their aboveground biomass (AGB), belowground biomass (BGB), total cover, and height in different number years of restoration land. Values $( \pm \mathrm{SE})$ are means of 3 squares. Different letters indicate significant differences at $p<0.05$.

\begin{tabular}{|c|c|c|c|c|c|c|}
\hline Site & $\begin{array}{l}\text { BGB0-30 } \\
\mathrm{cm}\left(\mathrm{g} / \mathrm{m}^{2}\right)\end{array}$ & $\begin{array}{l}\text { AGB } \\
\left(\mathrm{g} / \mathrm{m}^{2}\right)\end{array}$ & $\begin{array}{l}\text { Cover } \\
(\%)\end{array}$ & Height $(\mathrm{cm})$ & Species & \\
\hline R5 & $368.22 \pm 42.7$ & $41.87 \pm 8.01 \mathrm{~b}$ & $40 \pm 2.89 \mathrm{~b}$ & $20 \pm 1.16 b$ & $\begin{array}{l}\text { Stipa capillata } \\
\text { cristatum }\end{array}$ & Lin, Agropyron \\
\hline R10 & $504.19 \pm 119.98$ & $148.36 \pm 14.25 \mathrm{a}$ & $85 \pm 2.89 a$ & $49.33 \pm 2.33 a$ & $\begin{array}{l}\text { Stipa capillata } \\
\text { cristatum }\end{array}$ & Lin, Agropyron \\
\hline $\mathrm{R} 20$ & $281.37 \pm 92.37$ & $69.64 \pm 7.74 b$ & $30 \pm 2.89 \mathrm{~b}$ & $41.33 \pm 3.53 \mathrm{a}$ & $\begin{array}{l}\text { Stipa capillata } \\
\text { cristatum }\end{array}$ & Lin 、Agropyron \\
\hline
\end{tabular}

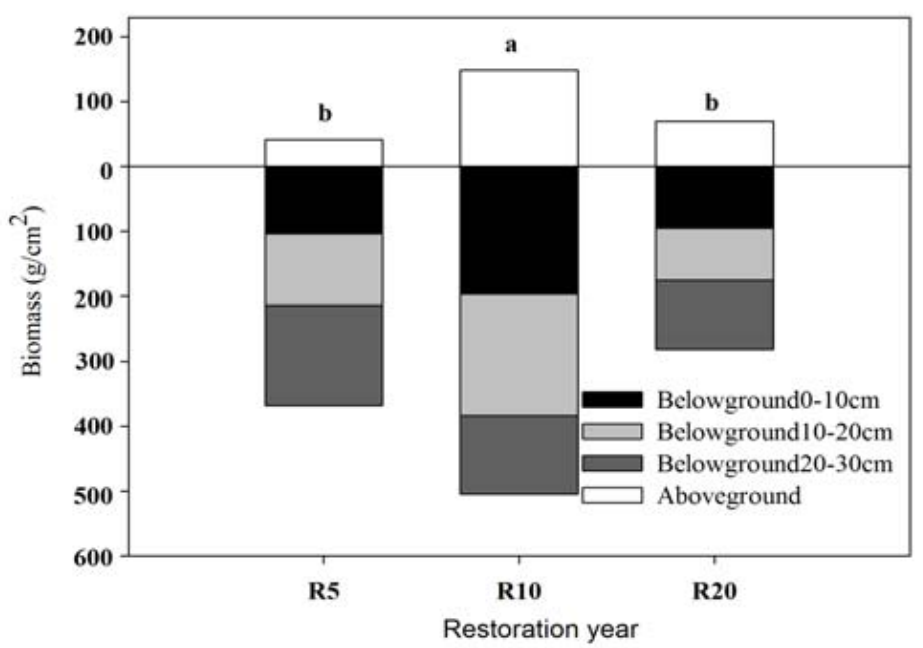

Figure 1. Aboveground and belowground biomass of land with different number years of restoration. Different letters indicate significant differences at $p<0.05$. 

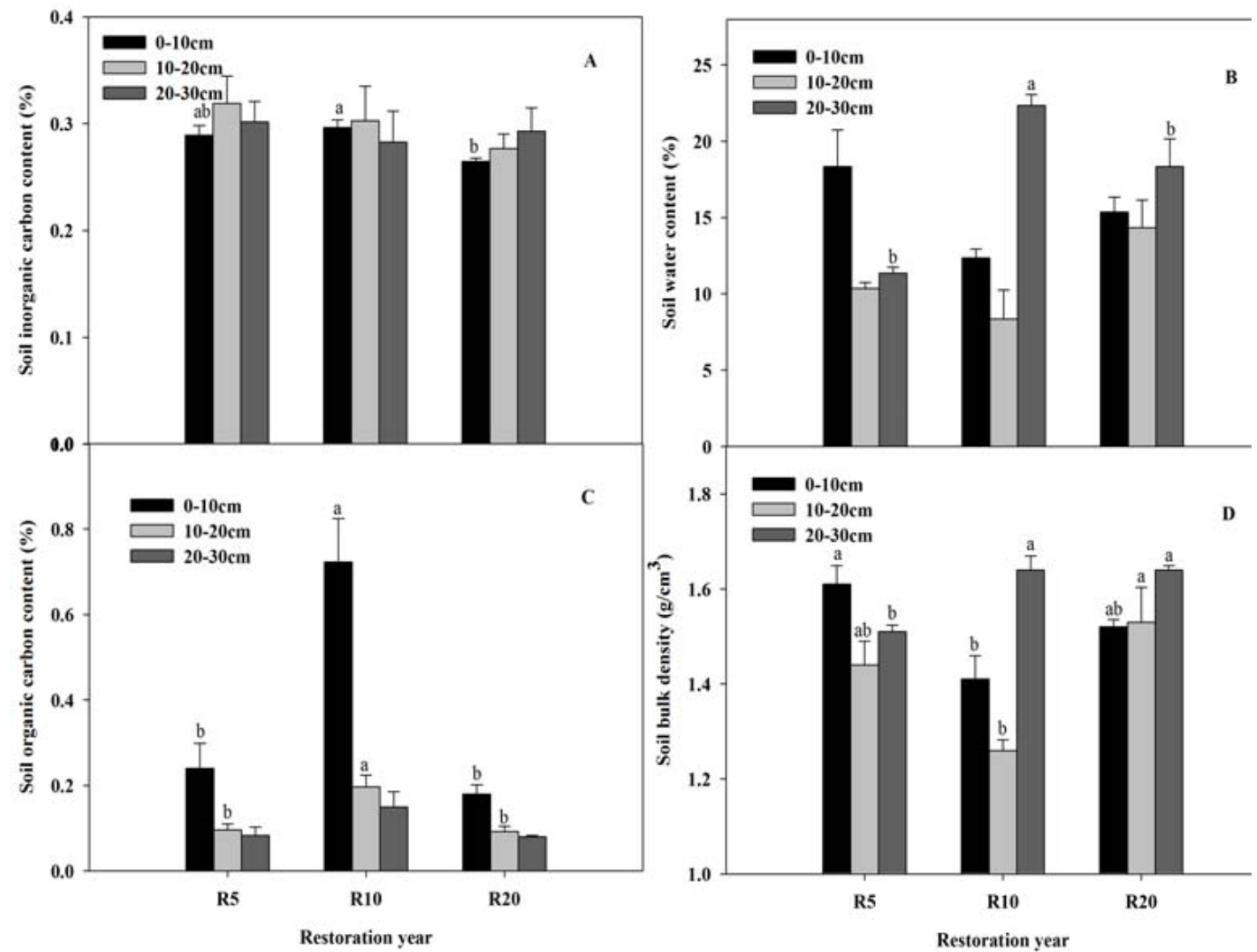

Figure 2. soil inorganic carbon content (A), soil water content (B), soil organic carboncontent (C) and soil bulk density (D) dynamics for three soil layers of $0-30 \mathrm{~cm}$ following the year of restoration. Values are in the form of Mean \pm SE and the sample size $n=3$. Different lower-case letters above the bars mean significant differences in the same soil layers among land restoration in different years $(p<0.05)$.

Correlation analyses showed that soil water content was significant negatively related to aboveground biomass $(\mathrm{F}=-0.742, p<0.01)$. There was a significant positive correlation between SOC content and aboveground biomass $(\mathrm{F}=0.825, p<0.01)$. Soil bulk density was significantly negatively related to coverage $(\mathrm{F}=-0.697, p<0.05)$, height $(\mathrm{F}=-0.682$, $p<0.05)$, above- $(\mathrm{F}=-0.903, p<0.01)$ and belowground $(\mathrm{F}=-0.552, p<0.01)$ biomass, while it was non-significant negatively relate to soil organic $(\mathrm{F}=$ $-0.269, p>0.05)$ and inorganic carbon contents $(\mathrm{F}=$ $-0.235, p>0.05$; Table 2). 
Table 2. Pearson correlation coefficients among restoration years, bulk density (BD), soil water content (SWC), cover, height, blow ground biomass (BGB), above ground biomass (AGB), soil organic (SOC) and inorganic carbon content (SIC) .

\begin{tabular}{|l|l|l|l|l|l|l|l|l|}
\hline & $\begin{array}{l}\mathrm{BD} \\
\left.\mathrm{g} / \mathrm{cm}^{3}\right)\end{array}$ & $\begin{array}{l}\text { SWC } \\
(\%)\end{array}$ & $\begin{array}{l}\text { Cover } \\
(\%)\end{array}$ & $\begin{array}{l}\text { Height } \\
(\mathrm{cm})\end{array}$ & $\begin{array}{l}\text { BGB } \\
\left(\mathrm{g} / \mathrm{m}^{2}\right)\end{array}$ & $\begin{array}{l}\text { AGB } \\
\left(\mathrm{g} / \mathrm{m}^{2}\right)\end{array}$ & $\begin{array}{l}\text { SOC } \\
(\%)\end{array}$ & $\begin{array}{l}\text { SIC } \\
(\%)\end{array}$ \\
\hline Years & 0.21 & 0.246 & -0.349 & 0.535 & -0.253 & 0.061 & -0.145 & -0.318 \\
\hline BD $\left(\mathrm{g} / \mathrm{cm}^{3}\right)$ & & $0.817^{* *}$ & $-0.697 *$ & $-0.682^{*}$ & $-0.552^{* *}$ & $-0.903^{* *}$ & -0.269 & -0.235 \\
\hline SWC $(\%)$ & & & -0.591 & -0.647 & -0.379 & $-0.742^{*}$ & -0.142 & -0.202 \\
\hline Cover $(\%)$ & & & & 0.548 & 0.598 & $0.885^{* *}$ & $0.089^{* *}$ & 0.655 \\
\hline Height $(\mathrm{cm})$ & & & & & 0.209 & $0.730^{*}$ & 0.600 & -0.037 \\
\hline BGB $\left(\mathrm{g} / \mathrm{m}^{2}\right)$ & & & & & & 0.665 & 0.306 & 0.246 \\
\hline AGB $\left(\mathrm{g} / \mathrm{m}^{2}\right)$ & & & & & & & $0.825^{* *}$ & 0.413 \\
\hline SOC $(\%)$ & & & & & & & & 0.105 \\
\hline
\end{tabular}

*indicates significant at $p<0.05$ and **indicates significant at $p<0.01$

\section{Discussion}

Establishment of artificial grassland was central for reclamation of soil in mine spoils in this study. 10year of restoration land showed significant more above- and belowground biomass than 5-year and 20year of restoration lands. It was consistent with the results of Chambers et al. (1994), who found that reclaimed areas already had a higher amount of biomass after 14 years of development. For the later 10-year period, the habitat conditions were extreme (toxic, excessively dry or acidic soils) (Markéta Hendrychová,
2008) and led to the biomass significantly reduced. In arid and semi-arid regions, water is a major factor in limiting the development of vegetation community. Some studies also found that factors related to water shortage may affect vegetation dynamics in reclaimed areas under dry climates (Martinez-Ruiz et al., 2007). However there was some experimental evidences that properly anthropogenic disturbance could stimulate plant sustainably growthed and increased plant fitness. Yang et al. (2012) found that mowing increased species richness by improving canopy radiation and facilitating seedling recruitment and plant growth. 
Socher et al. (2013) also found that mowing at intermediate levels generally enhanced plant species richness. Additional under proper stocking densities, grazing promoted plant species richness and plant productivity (Liu et al., 2012; Socher et al., 2013). In order to make full use of limited grassland resources, herders could moderate grazing or mowing on 10year of restoration land in the study region. Mowing regimes needed to be adapted to regional and local circumstances and grazing called for careful selection of livestock types and stocking densities.

It is necessary to analyze the properties of the reclaimed mine soil, because all physical and chemical soil characteristics are important components of the ecosystem structure. In our study we found that with the biomass reached maximum, soil water content to minimum at depth of $0-20 \mathrm{~cm}$. Correlation analyses showed that both above- and belowground biomass were negatively related to soil water content also proved the point. At depth of $20-30 \mathrm{~cm}$, soil water content increased in 10-year of restoration land. Gorman and Sencindiver (1999) measured soil development at reclaimed areas found soil aggregation and total porosity increased, and soil particle size distribution also changed after nine years of restoration. These changes in structure increased infiltration of surface water into the mine soil, contributed to less runoff and increased water retention (Underwood and Smeck, 2002), which was consistent with our point. There were distinct temporal changes in soil bulk density, low soil bulk density were found in 10-year of restoration land at depth of $0-20 \mathrm{~cm}$ due to the significantly increase of the belowground biomass. Thompson et al. (2000) reported that the development of root system could augment the biomass, and litter anthropogenic perturbation after years of reclamation have improved soil structure, decreased soil bulk density and increased porosity. Zhao et al. (2013) studied the effects of different plant species and time after reclamation on soil properties development indicated that reclamation significantly decreased the bulk density of the mined soil/spoil. Akala and Lal (2000) also found reclamation of mined lands decreased bulk density over a period of years. Apart from soil bulk density was significantly negatively related to belowground biomass, we also found that it was negatively related to SOC content. Growth and development of roots over time incorporated SOC and loosen up the soil, decreased soil bulk density. Land disturbance by mining caused drastic losses of SOC pool, Akala and Lal (2000) found the SOC pool of reclaimed mine soil increased over the duration of reclamation and planting grass increased SOC pool in the top depth. Bartuska and Frouz (2015) measurement of chronosequence sites of reclamation found soil carbon increased with site age but the rate of increasing declined with site age. 10-year of restoration land had the highest SOC content at all depths among distinct years of restoration lands which had the largest biomass, especially the belowground biomass. Root growth, mortality and turnover to SOC pool (Pucheta et al., 2004); defoliation increased root exudation and enhanced the amount of exuded carbon entered the soil (Hamilton and Frank, 2001; Kuzyakov et al., 2002). These all contributed to improvement of the SOC in restoration land. While a slight decreased of SOC content was found in 20-year restoration land, the trend was consist with the changed of biomass. Because plant roots made significant contributions to soil carbon under grassland (McNally et al., 2015). Lv and Liang (2012) also found that during forest restoration, SOC did not consistently increase linearly with restoration years.

\section{Conclusions}

Above- and belowground biomass, coverage, soil carbon and water content were all increased after years of restoration. Higher SOC and water content and 
lower soil bulk density were attributed to the growth of vegetation. Therefore, it was apparent from this study that establishment of artificial grassland was an effective restoration approach for improving soil carbon and water storage in reclaimed coal mine spoils. This may be true of other coal mine spoils without a long history of restoration. With the recover time increased, the biomass had a downward trend after 10 years of restoration. In order to stimulate plant growth, properly anthropogenic perturbations were necessary.

\section{Acknowledgment}

This research was funded by the Action Plan for West Development Project of Chinese Academy of Sciences (KZCX2-XB3-13), Projects of Natural Science Foundation of China (NSFC41371282, 41371242), Project of Natural Science Foundation of Shaanxi Province (2014KJXX-15).

\section{References}

Akala, V.A., Lal, R. 2000. Potential of mineland reclamation for soil carbon sequestration in Ohio. Land Degrad. Develop. 11, 289-297.

Akala, V.A., Lal, R. 2001. Soil organic carbon pools and sequestration rates in reclaimed mine soils in Ohio. J. Environ. Qual. 30, 2098-2104.

Barnhisel, R.I., Hower, J.M. 1997. Coal surface mine reclamation in the eastern United States: The revegetation of disturbed lands to hayland/pasture or cropland. Adv. Agron. 61, 233-275.

Bartuska, M., Frouz, J. 2015. Carbon accumulation and changes in soil chemistry in reclaimed opencast coal mining heaps near Sokolov using repeated measurement of chronosequence sites. Eur. J. Soil Sci. 66, 104-111.
Bradshaw, A.D. 1987. The reclamation of derelict land and the ecology of ecosystems. p. 53-74. In Jordan WR, III et al. (ed.) Restoration ecology: A synthesis approach to ecological research. Cambridge Univ. Press, Cambridge, U.K.

Chambers, J.C., Brown, R.W., Williams, B.D. 1994. An evaluation of reclamation success on Idaho's phosphate mines. Restor. Ecol. 1, 4-16.

Fu, Y., Lin, C.C., Ma, J.J., Zhu, T.C. 2010. Effect of plant types on physico-chemical properties of reclaimed mining soil in Inner Mongolia, China. Chin. Geogra. Sci. 20(4), 309-317.

Gorman, J.M., Sencindiver, J.C. 1999. Changes in minesoil physical properties over a nine-year period. 1, p. 245-253 In Proc. of the National Meeting of the Amer. Soc. for Surface Mining and Reclamation, Scottsdale, AZ.

Horváth, B., Opara-Nadi, O., Beese, F. 2005. A simple method for measuring the carbonate content of soils. Soil Sci. Soc. Am. J. 69, 1066-1068.

Juwarkar, A.A., Mehrotraa, K.L., Nair, R., Wanjari, T., Singh, S.K., Chakrabarti, T. 2010. Carbon sequestration in reclaimed manganese mine land at Gumgaon, India. Environ. Monit. Assess. 160, 457-464.

Keskin, T., Makineci, E. 2009. Some soil properties on coal mine spoils reclaimed with black locust (Robinia pceudoacacia L.) and umbrella pine (Pinus pinea L.) in AgacliIstanbul. Environ. Monit. Assess. 159, 407-414.

Kuzyakov, Y.K., Biryukova, O.B., Kuznetzova, T.K., Molter,K.M., Kandeler, E.K., Stahr, K.S. 2002. Carbon partitioning in plant and soil, carbon dioxide fluxes and enzyme activities as affected by cutting ryegrass. Biol. Fert. Soils 35, 348-358.

Liu, J.S., Wang, L., Wang, D.L., Bonser, S.P., Sun, F., Zhou, Y.F., Gao, Y., Teng, X. 2012. Plants can benefit from herbivory: stimulatory effects of sheep saliva on growth of leymus chinensis. Plos One 7(1):e29259. 
Li, H., Pei, J.B., Wang, J.K., Li, S.Y., Gao, G.W. 2013. Organic carbon density and storage of the major black soil regions in Northeast China. J. Soil Sci. Plant Nutr. 13(4), 883-893.

Lv, H., Liang, Z. 2012. Dynamics of soil organic carbon and dissolved organic carbon in Robina pseudoacacia forests. J. Soil Sci. Plant Nutr. 12(4), 763-774.

Markéta, Hendrychová. 2008. Reclamation success in post-mining landscapes in the Czech Republic: A review of pedological and biological studies. Journal of Landscape Studies 1, 63-78.

Martinez-Ruiz, C., Fernandez-Santos, B., Putwain, P.D., Fernandez-Gomez, M.J. 2007. Natural and man-induced revegetation on mining wastes: changes in the floristic composition during early succession. Ecol. Eng. 30, 286-294.

McNally, S.R., Laughlin, D.C., Rutledge, S., Dodd, M.B., Six, J., Schipper L.A. 2015. Root carbon inputs under moderately diverse sward and conventional ryegrass-clover pasture: implications for soil carbon sequestration. Plant Soil 1-11.

Nyamadzawo, G., Shukla, M.K., Lal, R. 2008. Spatial variability of total soil carbon and nitrogen stocks for some reclaimed minesoils of Southeastern Ohio. Land Degrad. Dev. 19, 275-288.

Pucheta, E., Bonamici, I., Cabido, M., Z. Diaz, Z. 2004. Below-ground biomass and productivity of a grazed site and a neighbouring ungrazed exclosure in a grassland in central Argentina. Austral Ecol. 29, 201-208.

Shrestha, R.K., Lal, R. 2011. Changes in physical and chemical properties of soil after surface mining and reclamation. Geoderma. 161, 168-176.

Stephanie, A., Socher, S.A., Prati, D., Boch, S., Müller, J., Baumbach, H., Gockel, S., Hemp, A., Schöning, I., Wells, K., Buscot, F., Kalko, EK.V., Linsenmair, K.E., Schulze, E.D., Weissere, W.W., Fischer, M. 2013. Interacting effects of fertiliza tion, mowing and grazing on plant species diversity of 1500 grasslands in Germany differ between regions. Basic Appl. Ecol. 14, 126-136.

Thomas, K.A., Sencindiver, J.C., Skousen, J.G., Gorman, J.M. 2000. Soil horizon development on a mountaintop surface mine in southern West Virginia. Green Lands. 30, 41-52.

Truong, X.V. 2013. Simultaneous measurement of soil organic and inorganic carbon: evaluation of a thermal gradient analysis. J. Soils Sediment 13, 1133-1140.

Ussiri, D.A.N., Lal, R., Jacinthe, P.A. 2006. Soil properties and carbon sequestration of afforested pastures in reclaimed minesoils of Ohio. Soil Sci. Am. J. 70, 1797-1806.

Underwood, J.F., Smeck, N.E. 2002. Soil development in two Ohio minesoils under continuous grass cover for twenty-five years following reclamation. the 2002 National Meetings of the American Society of Mining and Reclamation, Lexington, KY, June 9-13.

Wu, G.L., Liu, Z.H., Zhang, L., Hu, T.M., Chen, J.M. 2010. Effect of artificial grassland establishment on soil nutrients and carbon properties in a blacksoil-type degraded. Plant Soil. 333, 469-479.

Yang, H.J., Li, J., Li, L.H., Li, A., Wu, M.Y., Wan, S.Q. 2012. Diversity-dependent stability under mowing and nutrient addition: evidence from a 7-year grassland experiment. Ecol. Lett. 15, 619626.

Zhang, Y.N., Xu. L. 2012. Study on soil chemical properties in heidaigou mine dump. Journal of Inner Mongolia Agricultural University 33, 5-6:117-120.

Zhao, Z.Q., Shahrour, I., Bai, Z.K. 2013. Soils development in opencast coal mine spoils reclaimed for 1-13 years in the west-northern Loess Plateau of China. Eur. J. Soil Biol. 55, 40-46. 